Review

\title{
Interplay between apoptosis and autophagy in colorectal cancer
}

Copyright: Qian et al. This is an open-access article distributed under the terms of the Creative Commons Attribution License 3.0 (CC BY 3.0), which permits unrestricted use, distribution, and reproduction in any medium, provided the original author and source are credited.

\section{ABSTRACT}

\begin{abstract}
Autophagy and apoptosis are two pivotal mechanisms in mediating cell survival and death. Cross-talk of autophagy and apoptosis has been documented in the tumorigenesis and progression of cancer, while the interplay between the two pathways in colorectal cancer (CRC) has not yet been comprehensively summarized. In this study, we outlined the basis of apoptosis and autophagy machinery firstly, and then reviewed the recent evidence in cellular settings or animal studies regarding the interplay between them in CRC. In addition, several key factors that modulate the cross-talk between autophagy and apoptosis as well as its significance in clinical practice were discussed. Understanding of the interplay between the cell death mechanisms may benefit the translation of CRC treatment from basic research to clinical use.
\end{abstract}

\section{INTRODUCTION}

Colorectal cancer (CRC) refers to the development of cancer in the colon and the rectum. It is considered as one of the most commonly diagnosed malignancies and a leading cause of cancer death worldwide. It is estimated that 1.4 million people were newly diagnosed, and this disease resulted in 693,900 deaths in 2012 [1].

Multimodality therapy, including surgical resection, radiotherapy and chemotherapy, is currently applied for the treatment of CRC [2]. However, the five-year survival is poor in the CRC patients at advanced stage and chemotherapy resistance remains an unsolved problem for the management of this disorder. Despite targeted therapy using antibodies against vascular endothelial growth factor (VEGF) and epidermal growth factor receptor (EGFR) has achieved a considerably improved prognosis, the median survival period of patients with advanced CRC who received chemotherapy is still short ( $<3$ years) [2]. Novel therapeutic approaches and strategies are urgently needed for improving therapy responses and overcoming cancer resistance.
Apoptosis, a tightly controlled pathway, mediates cell death under physiological and pathological conditions, and has been known as a therapeutic target for CRC [3]. Autophagy is a cellular defensive pathway under starvation or upon stimuli that regulates the survival and death of CRC cells [4]. Emerging evidence highlight the importance of the interaction between these two cellular processes in CRC cells undergoing physiopathological changes. In this review article, we focus on the recent findings about the interplay between the two life and death partners in CRC. Our study provides valuable evidence for the translation of autophagy- and apoptosis-based basic science into clinical practice.

\section{Outline of cell death machinery}

The mechanism of apoptosis

Apoptosis is mainly divided into two signaling pathways, namely the intrinsic (mitochondrial mediated) and the extrinsic pathways. The intrinsic apoptosis initiates from intracellular stimuli, and is highly regulated by B-cell lymphoma-2 (Bcl-2) family members, such 
as pro-apoptotic proteins Bcl-2-associated X (Bax) and $\mathrm{Bcl}-2$ homologous antagonist/killer (Bak) as well as anti-apoptotic members Bcl-2 and B-cell lymphoma-X large (Bcl-xL) [5]. The pro-apoptotic proteins trigger the mitochondria-mediated cytochrome $\mathrm{C}$ release and induce Caspase cascade activation which ultimately leads to cell death. Such process can be inhibited by anti-apoptotic proteins. Extrinsic pathway is initiated via the activation of the death receptors. Induction of apoptosis is accepted as the principle aim for most anti-cancer therapies, including chemotherapy, radiotherapy, and immunotherapy [6].

\section{The mechanism of autophagy}

Autophagy is an evolutionarily conserved intracellular degradative pathway which removes cytoplasmic organelles and long-lived proteins upon starvation and serves as a self-defensive process [7]. Three subtypes of autophagy have been characterized, including macroautophagy, microautophagy, and chaperone-mediated autophagy (CMA) [8]. Macroautophagy begins with the formation of phagophore, which engulfs cytosol and delivers for degradation in lysosomes [9]. Microautophagy is the process by which lysosomes govern the engulfment of cytoplasmic materials. CMA is an autophagic pathway mediated by molecular chaperones. In this study, we mainly discuss the involvement of macroautophagy (hereafter referred to autophagy) in determining the fate of CRC cells.

\section{Interplay between autophagy and apoptosis in CRC cells}

\section{Concomitant occurrence and independent regulation}

Concurrent induction of apoptosis and autophagy has been documented in CRC cells and tumor-bearing nude mice in response to chemotherapeutic exposure or gene interference [10-15]. Autophagy may parallel with apoptosis in executing CRC cell death. Sequential occurrence of autophagy and apoptosis has been noted in CRC cells exposed to purvalanol, as purvalanol treatment induces an early autophagic response followed by apoptosis in HCT116 cells [16]. Moreover, these two programmed cell death pathways may drive cell death separately. Autophagy serves as an alternative cell death signaling in Bax and PUMA deficient human colon cancer cells that fail to undergo apoptosis [17]. Consistently, autophagy alone elicits cell death in apoptosis-resistant colon cancer cells [18]. On the other hand, apoptosis executes cell death in autophagy defective cells [19]. Based on this evidence, autophagy and apoptosis may act as cell death executioner, and drive cell death alternatively (Figure 1A).

\section{One leads to the other}

Inhibition of apoptosis using a pan-Caspase inhibitor z-VAD-fmk or by knocking down of Caspase-2 also blocks autophagy in HCT116 cells [20], indicating apoptosis may act as an upstream mediator of autophagy and activate autophagy in CRC cells (Figure 1B). In contrast, apoptosis inhibitor does not affect the justicidin A-induced autophagy induction in HT-29 cells, while blockage of autophagy by 3-methyladenine or silencing of autophagy related 5 (Atg5) inhibits apoptosis in these CRC cells [21]. In this case, autophagy drives apoptosis instead of being a downstream effecter.

\section{Autophagy antagonizes apoptosis}

Mice deficient in Atg5 exhibit increased expressions of cleaved Caspase 3 in colon tumors and reduced tumor size [22]. In accordance with this notion, pharmacological inhibition of autophagy or silencing of key autophagic genes has been shown to potentiate apoptosis signaling in CRC cells or colon cancer-bearing mice treated with anti-metabolites (e.g. 5-fluorouracil [5-FU] [23]), DNA disruption drugs (e.g. oxaliplatin [24, 25]), targeted therapy (e.g. celecoxib and an antagonist of Bcl-2/Bcl$x L$ [26], PI3K/mTOR inhibitor [27], BRAF inhibitor [28], niacin and tumor necrosis factor-related apoptosisinducing ligand [29], store-operated $\mathrm{Ca}^{2+}$ entry inhibitor [30], SN-38/CPT-11 [31]), other compounds or extracts (e.g. icaritin [32], tetrandrine [33], apigenin [34], purvalanol [35]), radiation therapy [36] and photodynamic therapy [37]. Moreover, endoplasmic reticulum (ER) stress appears to be a crucial intermediate event as inhibition of ER stress has been found to suppress autophagy and subsequently enhance apoptosis in sodium butyrate-treated CRC cells [38]. Defective autophagy enhances DNA damage and apoptosis in CRC cells exposed to radiation [36]. In this case, autophagy plays a pro-survival role, which prevents the accumulation of DNA damage sensors and ER stress products in tumor cells and facilitates the evasion of apoptosis (Figure 1C). Blockage of autophagy might be used as a strategy to sensitize CRC to apoptotic cell death. Co-administration of a reagent that is capable of inhibiting autophagy with an apoptosis inducer, such as fluorouracil, may provide a promising way to improve the sensitivity to chemotherapy [39].

\section{Factors modulating the cross-talk between autophagy and apoptosis}

Numerous factors and signaling pathways have been addressed to interconnect the autophagic and apoptotic pathways. Here, we discuss some of the apoptosis- or autophagy-related proteins that mediate the interplay between autophagy and apoptosis in CRCs (Table 1).

\section{Apoptosis-related proteins}

\section{Bcl-2 family proteins}

The expression of Bcl-2 family proteins is associated with the carcinogenesis and development 
of CRC. Inhibition of the anti-apoptotic proteins favors tumor growth suppression, as Bcl-2 inhibition sensitizes colon cancer cells to death [40], and mice deficient in Bcl$\mathrm{xL}$ have reduced intestinal tumor burden [41]. Restored Bax function augments mitochondrial apoptosis and reverses 5-FU resistance in CRC cells [42]. In addition, close association between $\mathrm{Bcl}-2$ family members and autophagy has also been noted. Bcl-2 and Bcl-xL bind to the $\mathrm{BH} 3$ domain of Beclin 1 and inhibit autophagy [43]. Such autophagy regulation governed by pro-survival $\mathrm{Bcl}-2$ members requires the involvement of Bax and Bak [44]. Pharmacological inhibition of Bcl-2 hinders the Bcl-2-Beclin 1 interaction, and results in the blockage of late stage autophagy in CRC cells [45]. In contrast, the dissociation of Bcl-xL from Beclin 1 facilitates the Beclin 1-dependent autophagy induction in CRC cells [46].

p53

p53 is a tumor suppressor gene that functions in inhibiting tumorigenesis by inducing cell cycle arrest and apoptosis [47]. Mutation of p53, leading to the dysfunction of p53 pathway, occurs in around 40\%-50\% patients with CRC [48]. Mutant p53 gains of autophagy inhibition function through interacting with a variety of autophagy-related proteins [49]. Reactivating p53 induces DNA damage and improves cell responses to 5-FU and oxaliplatin [50].

\section{Autophagy-related proteins}

\section{mTOR}

Mammalian target of rapamycin (mTOR) inhibits autophagy activation under basal conditions and serves as a negative regulator of autophagy machinery [51]. mTOR signaling pathway is regulated by diverse upstream signals, including AMP-activated kinase (AMPK) and phosphatidylinositol 3-kinase (PI3K) / protein kinase B (Akt) [52], both of which also contribute to apoptosis signaling in CRC cells in response to stimuli. For instance, activation of AMPK causes Caspase 8-mediated Beclin 1 cleavage and thus triggers apoptosis in CRC cells [53]. Inhibition of PI3K/Akt signaling pathway enhances CRC apoptosis [54, 55]. Celastrus orbiculatus extract induces the activation of autophagy and apoptosis in CRC cells through inhibiting mTOR signaling [54]. The protein expression of mTOR is higher in CRC than that in adjacent tissues [56], and the level of mTOR predicts poor prognosis for stage II CRC [57].

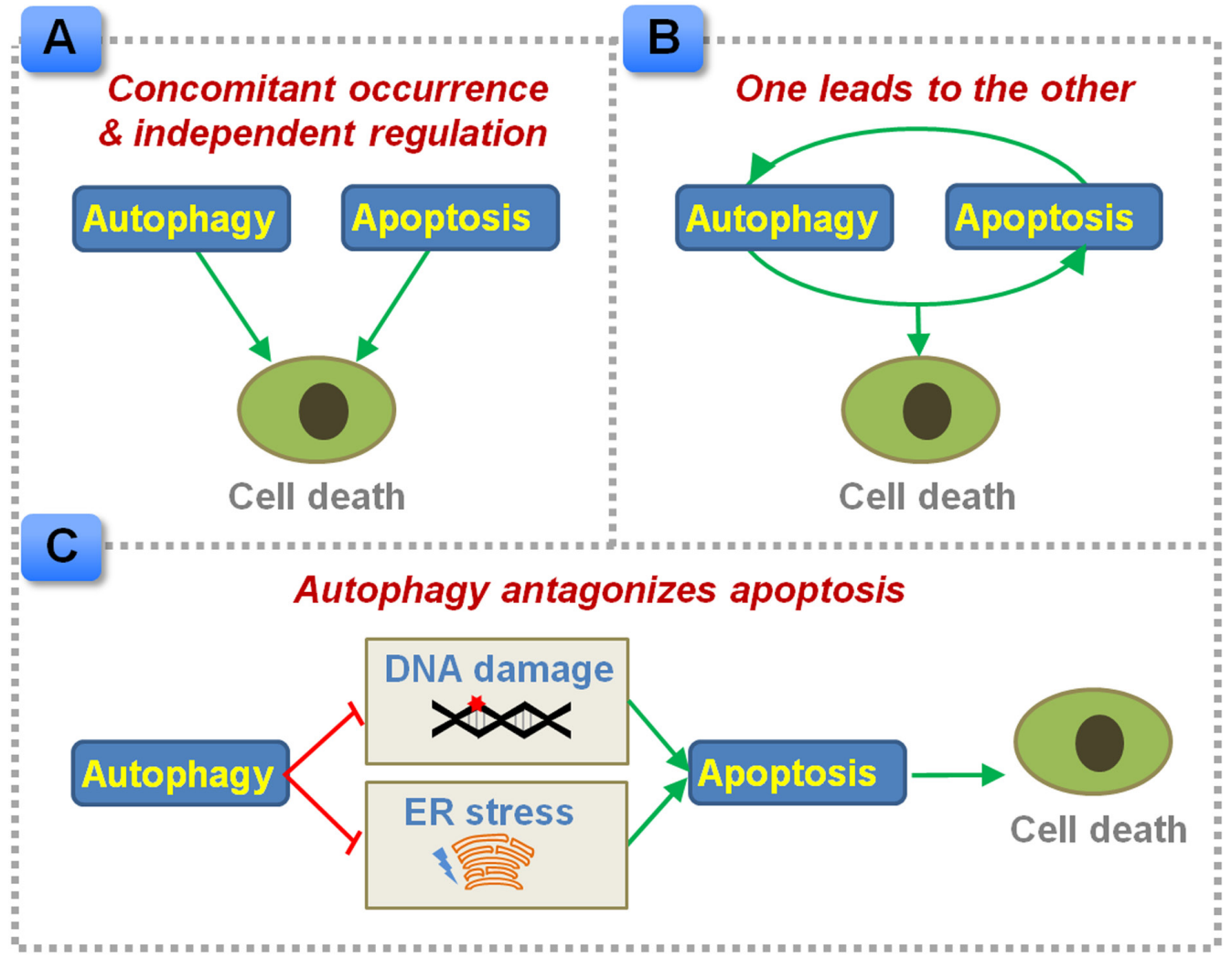

Figure 1: Proposed interplay between autophagy and apoptosis in regulating CRC cell death. (A) Autophagy and apoptosis can be induced concomitantly, and regulate cell death independently. (B) Autophagy and apoptosis, one leads to the other. (C) Autophagy antagonizes apoptotic cell death by preventing the accumulation of damaged DNA and ER stress products. 
Table 1: Dural role mediators of autophagy and apoptosis and their resulting effects on CRC

\begin{tabular}{|c|c|c|c|c|}
\hline Protein & $\begin{array}{l}\text { Autophagy } \\
\text { modulation }\end{array}$ & $\begin{array}{l}\text { Apoptosis } \\
\text { modulation }\end{array}$ & Expression in CRC & Role in CRC \\
\hline \multicolumn{5}{|c|}{ Apoptosis related proteins } \\
\hline Bcl-2 & $\begin{array}{l}\text { Binds to Beclin } 1 \text { and } \\
\text { inhibits autophagy } \\
\text { [43]. }\end{array}$ & $\begin{array}{l}\text { Anti-apoptosis } \\
\text { [84] }\end{array}$ & $\begin{array}{l}\text { Increased in low-grade } \\
\text { and early-stage tumors } \\
{[85] .}\end{array}$ & $\begin{array}{l}\text { Bcl-2 inhibition leads to the blockage of } \\
\text { late stage autophagy in CRC cells [45]. } \\
\text { The antisense oligonucleotide of Bcl-2 } \\
\text { sensitizes Bcl-2-positive human colon } \\
\text { cancer cells to radiation [40]. }\end{array}$ \\
\hline Bcl-xL & $\begin{array}{l}\text { Binds to Beclin } 1 \text { and } \\
\text { inhibits autophagy } \\
\text { [86]. }\end{array}$ & $\begin{array}{l}\text { Anti-apoptosis } \\
\text { [87] }\end{array}$ & $\begin{array}{l}\text { Increased in CRC [41], } \\
\text { and negatively associates } \\
\text { with overall survival } \\
\text { [88]. }\end{array}$ & $\begin{array}{l}\text { Oxaliplatin and bortezomib induce the } \\
\text { dissociation of Bcl-xL from Beclin } 1 \text { and } \\
\text { initiate autophagy in CRC cells [46]. } \\
\text { Prevents CRC cell apoptosis, drives } \\
\text { tumorigenesis and cancer progression } \\
\text { [41]. }\end{array}$ \\
\hline Bax & $\begin{array}{l}\text { Required for the } \\
\text { autophagy regulation } \\
\text { mediated by Bcl-2 and } \\
\text { Bcl-xL [44]. }\end{array}$ & $\begin{array}{l}\text { Pro-apoptosis } \\
\text { [89] }\end{array}$ & $\begin{array}{l}\text { Increased in CRC [90], } \\
\text { and decreases with } \\
\text { cancer progression [91]. }\end{array}$ & $\begin{array}{l}\text { Restored Bax function by andrographolide } \\
\text { promotes mitochondrial apoptosis and } \\
\text { reverses 5-FU resistance [42]. }\end{array}$ \\
\hline p53 & $\begin{array}{l}\text { Mutant p53 inhibits } \\
\text { autophagy [49]. }\end{array}$ & $\begin{array}{l}\text { Wild type p53, } \\
\text { pro-apoptosis } \\
\text { [48]; Mutant } \\
\text { p53, anti- } \\
\text { apoptosis [49]. }\end{array}$ & $\begin{array}{l}\text { p53 mutation occurs in } \\
40 \%-50 \% \text { CRC patients } \\
{[48] .}\end{array}$ & $\begin{array}{l}\text { The p53 reactivating drug RITA induces } \\
\text { DNA damage and sensitizes cells to } 5-\mathrm{FU} \\
\text { and oxaliplatin treatment }[50] \text {. }\end{array}$ \\
\hline \multicolumn{5}{|c|}{ Autophagy related proteins } \\
\hline mTOR & $\begin{array}{l}\text { Inhibits autophagy } \\
\text { [51]. }\end{array}$ & $\begin{array}{l}\text { Shares common } \\
\text { signaling in } \\
\text { regulating } \\
\text { apoptosis [52]. }\end{array}$ & $\begin{array}{l}\text { Increased in CRC [56]. } \\
\text { Predicts poor prognosis } \\
\text { for stage II CRC [57]. }\end{array}$ & $\begin{array}{l}\text { Celastrus orbiculatus extract induces the } \\
\text { activation of autophagy and apoptosis } \\
\text { in CRC cells through inhibiting mTOR } \\
\text { signaling [54]. }\end{array}$ \\
\hline $\operatorname{Atg} 5$ & $\begin{array}{l}\text { Required for } \\
\text { autophagosome } \\
\text { formation [63]. }\end{array}$ & $\begin{array}{l}\text { Calpain-induced } \\
\text { Atg5 cleavage } \\
\text { induces } \\
\text { apoptosis [58]. }\end{array}$ & $\begin{array}{l}\text { Decreased in CRC [59]. } \\
\text { Absent expression of } \\
\text { Atg5 associates with } \\
\text { poor prognosis [60]. }\end{array}$ & $\begin{array}{l}\text { Knocking down of Atg } 5 \text { sensitizes cells } \\
\text { to apoptosis induced by icaritin [32] or } \\
\text { propionate [61]. Heterozygous deletion of } \\
\text { Atg5 promotes the anti-tumor efficacy of } \\
\text { IFN- } \gamma \text { against intestinal adenomas in mice } \\
{[62] \text {. }}\end{array}$ \\
\hline Beclin 1 & $\begin{array}{l}\text { Required for } \\
\text { autophagosome } \\
\text { formation [63]. }\end{array}$ & $\begin{array}{l}\text { Beclin } 1 \\
\text { cleavage } \\
\text { augments } \\
\text { apoptosis [64]. }\end{array}$ & $\begin{array}{l}\text { Increased in CRC [66, } \\
67] \text {. High Beclin } 1 \\
\text { expression associates } \\
\text { with poor prognosis [68]. } \\
\text { High Beclin } 1 \text { expression } \\
\text { predicts better prognosis } \\
\text { [69]. }\end{array}$ & $\begin{array}{l}\text { Knocking down of Beclin } 1 \text { sensitizes } \\
\text { cells to icaritin-induced apoptosis [32]. } \\
\text { Spicatoside A triggers the autophagy-to- } \\
\text { apoptosis switch by inducing Beclin } 1 \\
\text { cleavage [65]. }\end{array}$ \\
\hline
\end{tabular}

5-FU, 5-fluorouracil; Bax, Bcl-2-associated X; Bcl-2, B-cell lymphoma-2; Bcl-xL, B-cell lymphoma-X large; CRC, colorectal cancer; IFN- $\gamma$, interferon- $\gamma$; mTOR, mammalian target of rapamycin; RITA, reactivating $\mathrm{p} 53$ and inducing tumor apoptosis. 


\section{Atg5}

Atg5 is an autophagy related gene participating in autophagy initiation. Yousefi et al. reveals an autophagyto-apoptosis switch pattern induced by Calpain-mediated Atg5 cleavage [58]. After cleavage, Atg5 translocates to mitochondria and elicits cytochrome $\mathrm{C}$ release and mitochondrial apoptosis [58]. The protein expression of Atg5 is decreased in CRC [59], and absent expression of Atg5 has been implicated to associate with poor prognosis of CRC patients [60]. In vitro and in vivo studies demonstrate that Atg5 deficiency sensitizes CRC cells to apoptosis [32, 61, 62].

\section{Beclin 1}

Beclin 1, a mammalian ortholog of yeast Atg6, mediates the formation of autophagosomes and therefore contributes to autophagy initiation [63]. Caspasemodulated Beclin 1 cleavage results in the loss of its autophagy activation function, and the cleaved Beclin 1 augments apoptosis by promoting the release of proapoptotic factors from mitochondria [64]. In CRC cells, Beclin 1-dependent autophagy appears to be required for the maintenance of tumor cell survival, as knocking down of Beclin 1 sensitizes cells to icaritin-induced apoptosis [32]. Spicatoside A triggers the autophagy-to-apoptosis switch in CRC cells by inducing Beclin 1 cleavage [65]. Hence, Beclin 1 might be a critical mediator of the crosstalk between two cell death pathways. Compared to the weak expression of Beclin 1 in normal mucosal cells of colon, the level of Beclin 1 is higher in CRC tissues [66, 67]. The prognostic significance of Beclin 1 for $\mathrm{CRC}$ is still under debating. A meta-analysis enrolling six articles indicates that high Beclin 1 expression associates with poor prognosis of CRC patients [68]. However, another research group suggests that high Beclin 1 expression predicts better prognosis of CRC [69].

\section{Significance in clinical practice}

Apoptotic signaling pathway is recognized as a potential therapeutic target for the management of CRC [3]. The efficacy of drugs targeting diverse mediators of the apoptotic cascade, such as death receptor 5 (DR5), Bcl-2 family proteins, and caspase activity, have been tested in pre-clinical and clinical trials for the treatment of CRC [70]. In recent years, great attention has been given to the importance of autophagic pathway in the chemotherapy resistance of cancer [71]. Autophagy is a novel and promising target for CRC therapy $[4,72]$ and may have considerable values for preventing the devastating occurrence of drug resistance. The mTOR inhibitors, temsirolimus [73] and everolimus [74], are rapamycin analogs that have been approved by the Food and Drug Administration (FDA) for the treatment of renal cell carcinoma. Phase I and phase II clinical trials of the autophagy stimulators for patients with $\mathrm{CRC}$ have been completed (For more details, See: www.clinicaltrials. gov). In a phase I clinical trial, a partial response is detected in one patient with advanced CRC after everolimus treatment [75]. A multicenter phase II study reveals that combined administration of everolimus with an angiogenesis inhibitor tivozanib achieves stable disease in $50 \%$ of patients with refractory metastatic CRC [76]. A recent study demonstrates that these rapamycin analogs are capable to provoke the extrinsic apoptotic pathway in CRC cells through regulating the DR5/Fas-associated protein with death domain (FADD)/Caspase-8 axis [77].

Autophagy inhibitor chloroquine (CQ) [78] and its analog hydroxychloroquine (HCQ) [79] impair autophagic degradation by disrupting lysosomal function. These agents have been approved by the FDA for the treatment of malaria, systemic lupus erythematosus, and rheumatoid arthritis. The anti-cancer activities of these autophagy inhibitors have been assessed in several clinical trials [80]. The efficacy of combined administration of HCQ and FOLFOX/Bevacizumab or Capecitabine/Oxaliplatin/ Bevacizumab for CRC patients has been evaluated in phase I and phase II clinical trials [80]. In addition, a phase I clinical trial reveals that, combined use of HCQ with vorinostat, a histone deacetylase inhibitor, achieves stable disease in two patients with CRC [81]. Although the underlying mechanism remains largely unclear, the combined therapy with HCQ and vorinostat has been found to improve anti-tumor immunity in refractory metastatic CRC patients [82]. Nevertheless, further investigation with larger sample size of CRC is still required for examination of the treatment efficacy of HCQ. Based on the animal and cell culture studies as discussed above, combined use of autophagy modulator may sensitize the CRC cells to chemotherapy and overcome the chemotherapy resistance.

\section{CONCLUSION}

Taken together, cell death signaling is complex and functions in coordination with one another. Here, we summarized the recent advances of the interplay between autophagy and apoptosis in modulating the survival and death of CRC cells. A better understanding of the molecular mechanisms involved in the carcinogenesis, progression and drug resistance of CRC may provide future directions of targeted therapies for this human malignancy. Nevertheless, it should be noted that, in addition to the classical programmed cell death processes mentioned in this study, other pathways, such as necrosis and necroptosis (programmed necrosis), also contribute to CRC cell death induced by anti-cancer therapy [70, 83]. Uncovering the mystery of cell death may open new window for CRC therapy. Moreover, there is considerable uncertainty regarding the prognostic values of the autophagy- or apoptosis-related factors in CRC. Evidence from large-scale clinical studies is therefore still required. 


\section{ACKNOWLEDGMENTS}

This study is supported by National Natural Science Foundation of China (81401043) and Zhejiang Provincial Natural Science Foundation of China (LY17H310005, LY17H160027).

\section{CONFLICTS OF INTEREST}

The authors declare no conflicts of interest.

\section{REFERENCES}

1. Torre LA, Bray F, Siegel RL, Ferlay J, Lortet-Tieulent J, Jemal A. Global cancer statistics, 2012. CA Cancer J Clin. 2015; 65: 87-108. doi: 10.3322/caac.21262.

2. Brenner H, Kloor M, Pox CP. Colorectal cancer. Lancet. 2014; 383: 1490-502. doi: 10.1016/ S0140-6736(13)61649-9.

3. Abraha AM, Ketema EB. Apoptotic pathways as a therapeutic target for colorectal cancer treatment. World J Gastrointest Oncol. 2016; 8: 583-91. doi: 10.4251/wjgo. v8.i8.583.

4. Burada F, Nicoli ER, Ciurea ME, Uscatu DC, Ioana M, Gheonea DI. Autophagy in colorectal cancer: an important switch from physiology to pathology. World J Gastrointest Oncol. 2015; 7: 271-84. doi: 10.4251/wjgo. v7.i11.271.

5. Takahashi Y, Karbowski M, Yamaguchi H, Kazi A, Wu J, Sebti SM, Youle RJ, Wang HG. Loss of Bif-1 suppresses Bax/Bak conformational change and mitochondrial apoptosis. Mol Cell Biol. 2005; 25: 9369-82. doi: 10.1128/ MCB.25.21.9369-9382.2005.

6. Nonnenmacher L, Hasslacher S, Zimmermann J, KarpelMassler G, La Ferla-Bruhl K, Barry SE, Burster T, Siegelin MD, Bruhl O, Halatsch ME, Debatin KM, Westhoff MA. Cell death induction in cancer therapy - past, present, and future. Crit Rev Oncog. 2016; 21: 253-67. doi: 10.1615/ CritRevOncog.2016016987.

7. Hale AN, Ledbetter DJ, Gawriluk TR, Rucker EB 3rd. Autophagy: regulation and role in development. Autophagy. 2013; 9: 951-72. doi: 10.4161/auto.24273.

8. Qian HR, Yang Y. Functional role of autophagy in gastric cancer. Oncotarget. 2016; 7: 17641-51. doi: 10.18632/ oncotarget. 7508 .

9. Coly PM, Gandolfo P, Castel H, Morin F. The autophagy machinery: a new player in chemotactic cell migration. Front Neurosci. 2017; 11: 78. doi: 10.3389/ fnins.2017.00078.

10. Zhao S, Chen SR, Yang XF, Shen DF, Takano Y, Su RJ, Zheng HC. BTG1 might be employed as a biomarker for carcinogenesis and a target for gene therapy in colorectal cancers. Oncotarget. 2017; 8: 7502-20. doi: 10.18632/ oncotarget.10649.
11. Lee HY, Chung KJ, Hwang IH, Gwak J, Park S, Ju BG, Yun E, Kim DE, Chung YH, Na M, Song GY, Oh S. Activation of p53 with ilimaquinone and ethylsmenoquinone, marine sponge metabolites, induces apoptosis and autophagy in colon cancer cells. Mar Drugs. 2015; 13: 543-57. doi: 10.3390/md13010543.

12. Colangelo T, Polcaro G, Ziccardi P, Muccillo L, Galgani M, Pucci B, Milone MR, Budillon A, Santopaolo M, Mazzoccoli G, Matarese G, Sabatino L, Colantuoni V. The miR-27a-calreticulin axis affects drug-induced immunogenic cell death in human colorectal cancer cells. Cell Death Dis. 2016; 7: e2108. doi: 10.1038/cddis.2016.29.

13. Huangfu L, Liang H, Wang G, Su X, Li L, Du Z, Hu M, Dong Y, Bai X, Liu T, Yang B, Shan H. miR-183 regulates autophagy and apoptosis in colorectal cancer through targeting of UVRAG. Oncotarget. 2016; 7: 4735-45. doi: 10.18632/oncotarget.6732.

14. Shan TD, Xu JH, Yu T, Li JY, Zhao LN, Ouyang H, Luo S, Lu XJ, Huang CZ, Lan QS, Zhong W, Chen QK. Knockdown of linc-POU3F3 suppresses the proliferation, apoptosis, and migration resistance of colorectal cancer. Oncotarget. 2016; 7: 961-75. doi: 10.18632/ oncotarget.5830.

15. Cottone L, Capobianco A, Gualteroni C, Perrotta C, Bianchi ME, Rovere-Querini P, Manfredi AA. 5-Fluorouracil causes leukocytes attraction in the peritoneal cavity by activating autophagy and HMGB1 release in colon carcinoma cells. Int J Cancer. 2015; 136: 1381-9. doi: 10.1002/ijc.29125.

16. Coker-Gurkan A, Arisan ED, Obakan P, Akalin K, Ozbey U, Palavan-Unsal N. Purvalanol induces endoplasmic reticulum stress-mediated apoptosis and autophagy in a time-dependent manner in HCT116 colon cancer cells. Oncol Rep. 2015; 33: 2761-70. doi: 10.3892/or.2015.3918.

17. Xiong HY, Guo XL, Bu XX, Zhang SS, Ma NN, Song JR, Hu F, Tao SF, Sun K, Li R, Wu MC, Wei LX. Autophagic cell death induced by 5-FU in Bax or PUMA deficient human colon cancer cell. Cancer Lett. 2010; 288: 68-74. doi: 10.1016/j.canlet.2009.06.039.

18. Hu T, Wang L, Zhang L, Lu L, Shen J, Chan RL, Li M, Wu WK, To KK, Cho CH. Sensitivity of apoptosis-resistant colon cancer cells to tanshinones is mediated by autophagic cell death and p53-independent cytotoxicity. Phytomedicine. 2015; 22: 536-44. doi: 10.1016/j.phymed.2015.03.010.

19. Amin A, Bajbouj K, Koch A, Gandesiri M, SchneiderStock R. Defective autophagosome formation in p53-null colorectal cancer reinforces crocin-induced apoptosis. Int J Mol Sci. 2015; 16: 1544-61. doi: 10.3390/ijms16011544.

20. Wang L, Hu T, Shen J, Zhang L, Chan RL, Lu L, Li M, Cho $\mathrm{CH}, \mathrm{Wu}$ WK. Dihydrotanshinone I induced apoptosis and autophagy through caspase dependent pathway in colon cancer. Phytomedicine. 2015; 22: 1079-87. doi: 10.1016/j. phymed.2015.08.009.

21. Won SJ, Yen CH, Liu HS, Wu SY, Lan SH, Jiang-Shieh YF, Lin CN, Su CL. Justicidin A-induced autophagy flux enhances apoptosis of human colorectal cancer cells via 
class III PI3K and Atg5 pathway. J Cell Physiol. 2015; 230: 930-46. doi: 10.1002/jcp.24825.

22. Sakitani K, Hirata Y, Hikiba Y, Hayakawa Y, Ihara S, Suzuki H, Suzuki N, Serizawa T, Kinoshita H, Sakamoto K, Nakagawa H, Tateishi K, Maeda S, et al. Inhibition of autophagy exerts anti-colon cancer effects via apoptosis induced by p53 activation and ER stress. BMC Cancer. 2015; 15: 795. doi: 10.1186/s12885-015-1789-5.

23. Sasaki K, Tsuno NH, Sunami E, Kawai K, Hongo K, Hiyoshi M, Kaneko M, Murono K, Tada N, Nirei T, Takahashi K, Kitayama J. Resistance of colon cancer to 5-fluorouracil may be overcome by combination with chloroquine, an in vivo study. Anticancer Drugs. 2012; 23: 675-82. doi: 10.1097/CAD.0b013e328353f8c7.

24. Shi Y, Han Y, Xie F, Wang A, Feng X, Li N, Guo H, Chen D. ASPP2 enhances oxaliplatin (L-OHP)-induced colorectal cancer cell apoptosis in a p53-independent manner by inhibiting cell autophagy. J Cell Mol Med. 2015; 19: 53543. doi: $10.1111 / \mathrm{jcmm} .12435$.

25. Liu W, Zhang Z, Zhang Y, Chen X, Guo S, Lei Y, Xu Y, Ji C, Bi Z, Wang K. HMGB1-mediated autophagy modulates sensitivity of colorectal cancer cells to oxaliplatin via MEK/ ERK signaling pathway. Cancer Biol Ther. 2015; 16: 511-7. doi: 10.1080/15384047.2015.1017691.

26. Huang S, Sinicrope FA. Celecoxib-induced apoptosis is enhanced by ABT-737 and by inhibition of autophagy in human colorectal cancer cells. Autophagy. 2010; 6: 256-69.

27. Yang X, Niu B, Wang L, Chen M, Kang X, Wang L, Ji Y, Zhong J. Autophagy inhibition enhances colorectal cancer apoptosis induced by dual phosphatidylinositol 3-kinase/ mammalian target of rapamycin inhibitor NVP-BEZ235. Oncol Lett. 2016; 12: 102-6. doi: 10.3892/ol.2016.4590.

28. Sueda T, Sakai D, Kawamoto K, Konno M, Nishida N, Koseki J, Colvin H, Takahashi H, Haraguchi N, Nishimura J, Hata T, Takemasa I, Mizushima T, et al. BRAF V600E inhibition stimulates AMP-activated protein kinasemediated autophagy in colorectal cancer cells. Sci Rep. 2016; 6: 18949. doi: 10.1038/srep18949.

29. Kim SW, Lee JH, Moon JH, Nazim UM, Lee YJ, Seol JW, Hur J, Eo SK, Lee JH, Park SY. Niacin alleviates TRAILmediated colon cancer cell death via autophagy flux activation. Oncotarget. 2016; 7: 4356-68. doi: 10.18632/ oncotarget.5374.

30. Jing Z, Sui X, Yao J, Xie J, Jiang L, Zhou Y, Pan H, Han W. SKF-96365 activates cytoprotective autophagy to delay apoptosis in colorectal cancer cells through inhibition of the calcium/CaMKIIgamma/AKT-mediated pathway. Cancer Lett. 2016; 372: 226-38. doi: 10.1016/j.canlet.2016.01.006.

31. Chen P, Luo X, Nie P, Wu B, Xu W, Shi X, Chang H, Li B, Yu X, Zou Z. CQ synergistically sensitizes human colorectal cancer cells to SN-38/CPT-11 through lysosomal and mitochondrial apoptotic pathway via p53-ROS cross-talk. Free Radic Biol Med. 2017; 104: 280-97. doi: 10.1016/j.freeradbiomed.2017.01.033.
32. Zhou C, Gu J, Zhang G, Dong D, Yang Q, Chen MB, Xu D. AMPK-autophagy inhibition sensitizes icaritin-induced anti-colorectal cancer cell activity. Oncotarget. 2017; 8: 14736-47. doi: 10.18632/oncotarget.14718.

33. Mei L, Chen Y, Wang Z, Wang J, Wan J, Yu C, Liu X, Li W. Synergistic anti-tumour effects of tetrandrine and chloroquine combination therapy in human cancer: a potential antagonistic role for p21. Br J Pharmacol. 2015; 172: 2232-45. doi: 10.1111/bph.13045.

34. Lee Y, Sung B, Kang YJ, Kim DH, Jang JY, Hwang SY, Kim M, Lim HS, Yoon JH, Chung HY, Kim ND. Apigenininduced apoptosis is enhanced by inhibition of autophagy formation in HCT116 human colon cancer cells. Int J Oncol. 2014; 44: 1599-606. doi: 10.3892/ijo.2014.2339.

35. Coker-Gurkan A, Arisan ED, Obakan P, Guvenir E, Unsal NP. Inhibition of autophagy by 3-MA potentiates purvalanol-induced apoptosis in Bax deficient HCT 116 colon cancer cells. Exp Cell Res. 2014; 328: 87-98. doi: 10.1016/j.yexcr.2014.07.022.

36. Park JM, Tougeron D, Huang S, Okamoto K, Sinicrope FA. Beclin 1 and UVRAG confer protection from radiationinduced DNA damage and maintain centrosome stability in colorectal cancer cells. PLoS One. 2014; 9: e100819. doi: 10.1371/journal.pone.0100819.

37. Xiong L, Liu Z, Ouyang G, Lin L, Huang H, Kang H, Chen W, Miao X, Wen Y. Autophagy inhibition enhances photocytotoxicity of Photosan-II in human colorectal cancer cells. Oncotarget. 2017; 8: 6419-32. doi: 10.18632/ oncotarget.14117.

38. Zhang J, Yi M, Zha L, Chen S, Li Z, Li C, Gong M, Deng H, Chu X, Chen J, Zhang Z, Mao L, Sun S. Sodium butyrate induces endoplasmic reticulum stress and autophagy in colorectal cells: implications for apoptosis. PLoS One. 2016; 11: e0147218. doi: 10.1371/journal.pone.0147218.

39. Feng Y, Gao S, Gao Y, Wang X, Chen Z. AntiEGFR antibody sensitizes colorectal cancer stem-like cells to Fluorouracil-induced apoptosis by affecting autophagy. Oncotarget. 2016; 7: 81402-9. doi: 10.18632/ oncotarget.13233.

40. Wiedenmann N, Koto M, Raju U, Milas L, Mason KA. Modulation of tumor radiation response with G3139, a bcl-2 antisense oligonucleotide. Invest New Drugs. 2007; 25: 411-6. doi: 10.1007/s10637-007-9058-3.

41. Scherr AL, Gdynia G, Salou M, Radhakrishnan P, Duglova K, Heller A, Keim S, Kautz N, Jassowicz A, Elssner C, He YW, Jaeger D, Heikenwalder M, et al. Bcl-xL is an oncogenic driver in colorectal cancer. Cell Death Dis. 2016; 7: e2342. doi: 10.1038/cddis.2016.233.

42. Wang W, Guo W, Li L, Fu Z, Liu W, Gao J, Shu Y, Xu Q, Sun Y, Gu Y. Andrographolide reversed 5-FU resistance in human colorectal cancer by elevating BAX expression. Biochem Pharmacol. 2016; 121: 8-17. doi: 10.1016/j. bcp.2016.09.024. 
43. Fu LL, Cheng Y, Liu B. Beclin-1: autophagic regulator and therapeutic target in cancer. Int J Biochem Cell Biol. 2013; 45: 921-4. doi: 10.1016/j.biocel.2013.02.007.

44. Lindqvist LM, Heinlein $M$, Huang DC, Vaux DL. Prosurvival Bcl-2 family members affect autophagy only indirectly, by inhibiting Bax and Bak. Proc Natl Acad Sci U S A. 2014; 111: 8512-7. doi: 10.1073/pnas.1406425111.

45. Koehler BC, Jassowicz A, Scherr AL, Lorenz S, Radhakrishnan P, Kautz N, Elssner C, Weiss J, Jaeger D, Schneider M, Schulze-Bergkamen H. Pan-Bcl-2 inhibitor Obatoclax is a potent late stage autophagy inhibitor in colorectal cancer cells independent of canonical autophagy signaling. BMC Cancer. 2015; 15: 919. doi: 10.1186/ s12885-015-1929-y.

46. Kim SY, Song X, Zhang L, Bartlett DL, Lee YJ. Role of Bcl-xL/Beclin-1 in interplay between apoptosis and autophagy in oxaliplatin and bortezomib-induced cell death. Biochem Pharmacol. 2014; 88: 178-88. doi: 10.1016/j. bcp.2014.01.027.

47. Wang X, Simpson ER, Brown KA. p53: protection against tumor growth beyond effects on cell cycle and apoptosis. Cancer Res. 2015; 75: 5001-7. doi: 10.1158/0008-5472. CAN-15-0563.

48. Li XL, Zhou J, Chen ZR, Chng WJ. P53 mutations in colorectal cancer - molecular pathogenesis and pharmacological reactivation. World J Gastroenterol. 2015; 21: 84-93. doi: 10.3748/wjg.v21.i1.84.

49. Cordani M, Oppici E, Dando I, Butturini E, Dalla Pozza E, Nadal-Serrano M, Oliver J, Roca P, Mariotto S, Cellini B, Blandino G, Palmieri M, Di Agostino S, et al. Mutant p53 proteins counteract autophagic mechanism sensitizing cancer cells to mTOR inhibition. Mol Oncol. 2016; 10: 1008-29. doi: 10.1016/j.molonc.2016.04.001.

50. Wiegering A, Matthes N, Muhling B, Koospal M, Quenzer A, Peter S, Germer CT, Linnebacher M, Otto C. Reactivating p53 and inducing tumor apoptosis (RITA) enhances the response of RITA-sensitive colorectal cancer cells to chemotherapeutic agents 5-fluorouracil and oxaliplatin. Neoplasia. 2017; 19: 301-9. doi: 10.1016/j. neo.2017.01.007.

51. Klionsky DJ. The molecular machinery of autophagy: unanswered questions. J Cell Sci. 2005; 118: 7-18. doi: $10.1242 /$ jcs.01620.

52. Eisenberg-Lerner A, Bialik S, Simon HU, Kimchi A. Life and death partners: apoptosis, autophagy and the cross-talk between them. Cell Death Differ. 2009; 16: 966-75. doi: 10.1038/cdd.2009.33.

53. Song X, Kim SY, Zhang L, Tang D, Bartlett DL, Kwon YT, Lee YJ. Role of AMP-activated protein kinase in crosstalk between apoptosis and autophagy in human colon cancer. Cell Death Dis. 2014; 5: e1504. doi: 10.1038/ cddis.2014.463.

54. Yang L, Liu Y, Wang M, Qian Y, Dai X, Zhu Y, Chen J, Guo S, Hisamitsu T. Celastrus orbiculatus extract triggers apoptosis and autophagy via PI3K/Akt/mTOR inhibition in human colorectal cancer cells. Oncol Lett. 2016; 12: 37718. doi: 10.3892/ol.2016.5213.

55. Chen J, Wang Z, Yu S. AIM2 regulates viability and apoptosis in human colorectal cancer cells via the PI3K/Akt pathway. Onco Targets Ther. 2017; 10: 811-7. doi: 10.2147/ OTT.S125039.

56. Wu S, Sun C, Tian D, Li Y, Gao X, He S, Li T. Expression and clinical significances of Beclin1, LC3 and mTOR in colorectal cancer. Int J Clin Exp Pathol. 2015; 8: 3882-91.

57. Cai Z, Ke J, He X, Yuan R, Chen Y, Wu X, Wang L, Wang J, Lan P, Wu X. Significance of mTOR signaling and its inhibitor against cancer stem-like cells in colorectal cancer. Ann Surg Oncol. 2014; 21: 179-88. doi: 10.1245/ s10434-013-3146-8.

58. Yousefi S, Perozzo R, Schmid I, Ziemiecki A, Schaffner T, Scapozza L, Brunner T, Simon HU. Calpain-mediated cleavage of Atg5 switches autophagy to apoptosis. Nat Cell Biol. 2006; 8: 1124-32. doi: 10.1038/ncb1482.

59. Cho DH, Jo YK, Kim SC, Park IJ, Kim JC. Down-regulated expression of ATG5 in colorectal cancer. Anticancer Res. 2012; 32: 4091-6.

60. Choi JH, Cho YS, Ko YH, Hong SU, Park JH, Lee MA. Absence of autophagy-related proteins expression is associated with poor prognosis in patients with colorectal adenocarcinoma. Gastroenterol Res Pract. 2014; 2014: 179586. doi: 10.1155/2014/179586.

61. Tang Y, Chen Y, Jiang H, Nie D. Short-chain fatty acids induced autophagy serves as an adaptive strategy for retarding mitochondria-mediated apoptotic cell death. Cell Death Differ. 2011; 18: 602-18. doi: 10.1038/cdd.2010.117.

62. Wang L, Wang Y, Lu Y, Zhang Q, Qu X. Heterozygous deletion of ATG5 in Apc(Min/+) mice promotes intestinal adenoma growth and enhances the antitumor efficacy of interferon-gamma. Cancer Biol Ther. 2015; 16: 383-91. doi: 10.1080/15384047.2014.1002331.

63. Xie Z, Klionsky DJ. Autophagosome formation: core machinery and adaptations. Nat Cell Biol. 2007; 9: 1102-9. doi: 10.1038/ncb1007-1102.

64. Wirawan E, Vande Walle L, Kersse K, Cornelis S, Claerhout S, Vanoverberghe I, Roelandt R, De Rycke R, Verspurten J, Declercq W, Agostinis P, Vanden Berghe T, Lippens S, et al. Caspase-mediated cleavage of Beclin-1 inactivates Beclin1 -induced autophagy and enhances apoptosis by promoting the release of proapoptotic factors from mitochondria. Cell Death Dis. 2010; 1: e18. doi: 10.1038/cddis.2009.16.

65. Kim WK, Pyee Y, Chung HJ, Park HJ, Hong JY, Son KH, Lee SK. Antitumor activity of spicatoside A by modulation of autophagy and apoptosis in human colorectal cancer cells. J Nat Prod. 2016; 79: 1097-104. doi: 10.1021/acs. jnatprod.6b00006.

66. Ahn CH, Jeong EG, Lee JW, Kim MS, Kim SH, Kim SS, Yoo NJ, Lee SH. Expression of beclin-1, an autophagy-related 
protein, in gastric and colorectal cancers. APMIS. 2007; 115: 1344-9. doi: 10.1111/j.1600-0463.2007.00858.x.

67. Liu L, Meng T, Wang QS, Jin HZ, Sun ZQ, Jin B, Fang F, Wang HJ. Association of Beclin-1 and microRNA-30a expression with the severity and treatment response of colorectal cancer. Genet Mol Res. 2016; 15. doi: 10.4238/ gmr.15027704.

68. Han Y, Xue XF, Shen HG, Guo XB, Wang X, Yuan B, Guo XP, Kuang YT, Zhi QM, Zhao H. Prognostic significance of Beclin-1 expression in colorectal cancer: a meta-analysis. Asian Pac J Cancer Prev. 2014; 15: 4583-7.

69. Yang Z, Ghoorun RA, Fan X, Wu P, Bai Y, Li J, Chen H, Wang L, Wang J. High expression of Beclin-1 predicts favorable prognosis for patients with colorectal cancer. Clin Res Hepatol Gastroenterol. 2015; 39: 98-106. doi: 10.1016/j.clinre.2014.06.014.

70. Koehler BC, Jager D, Schulze-Bergkamen H. Targeting cell death signaling in colorectal cancer: current strategies and future perspectives. World J Gastroenterol. 2014; 20: 192334. doi: 10.3748/wjg.v20.i8.1923.

71. Sui X, Chen R, Wang Z, Huang Z, Kong N, Zhang M, Han W, Lou F, Yang J, Zhang Q, Wang X, He C, Pan H. Autophagy and chemotherapy resistance: a promising therapeutic target for cancer treatment. Cell Death Dis. 2013; 4: e838. doi: 10.1038/cddis.2013.350.

72. Gil J, Pesz KA, Sasiadek MM. May autophagy be a novel biomarker and antitumor target in colorectal cancer? Biomark Med. 2016; 10: 1081-94. doi: 10.2217/ bmm-2016-0083.

73. Yazbeck VY, Buglio D, Georgakis GV, Li Y, Iwado E, Romaguera JE, Kondo S, Younes A. Temsirolimus downregulates p21 without altering cyclin D1 expression and induces autophagy and synergizes with vorinostat in mantle cell lymphoma. Exp Hematol. 2008; 36: 443-50. doi: 10.1016/j.exphem.2007.12.008.

74. Alonso MM, Jiang H, Yokoyama T, Xu J, Bekele NB, Lang FF, Kondo S, Gomez-Manzano C, Fueyo J. Delta-24-RGD in combination with RAD001 induces enhanced anti-glioma effect via autophagic cell death. Mol Ther. 2008; 16: 487 93. doi: 10.1038/sj.mt.6300400.

75. Tabernero J, Rojo F, Calvo E, Burris H, Judson I, Hazell K, Martinelli E, Ramon y Cajal S, Jones S, Vidal L, Shand N, Macarulla T, Ramos FJ, et al. Dose- and schedule-dependent inhibition of the mammalian target of rapamycin pathway with everolimus: a phase I tumor pharmacodynamic study in patients with advanced solid tumors. J Clin Oncol. 2008; 26: 1603-10. doi: 10.1200/JCO.2007.14.5482.

76. Wolpin BM, Ng K, Zhu AX, Abrams T, Enzinger PC, McCleary NJ, Schrag D, Kwak EL, Allen JN, Bhargava P, Chan JA, Goessling W, Blaszkowsky LS, et al. Multicenter phase II study of tivozanib (AV-951) and everolimus (RAD001) for patients with refractory, metastatic colorectal cancer. Oncologist. 2013; 18: 377-8. doi: 10.1634/ theoncologist.2012-0378.
77. He K, Zheng X, Li M, Zhang L, Yu J. mTOR inhibitors induce apoptosis in colon cancer cells via CHOP-dependent DR5 induction on 4E-BP1 dephosphorylation. Oncogene. 2016; 35: 148-57. doi: 10.1038/onc.2015.79.

78. Glaumann H, Ahlberg J. Comparison of different autophagic vacuoles with regard to ultrastructure, enzymatic composition, and degradation capacity--formation of crinosomes. Exp Mol Pathol. 1987; 47: 346-62.

79. Boya P, Gonzalez-Polo RA, Casares N, Perfettini JL, Dessen P, Larochette N, Metivier D, Meley D, Souquere S, Yoshimori T, Pierron G, Codogno P, Kroemer G. Inhibition of macroautophagy triggers apoptosis. Mol Cell Biol. 2005; 25: 1025-40. doi: 10.1128/MCB.25.3.1025-1040.2005.

80. Carew JS, Kelly KR, Nawrocki ST. Autophagy as a target for cancer therapy: new developments. Cancer Manag Res. 2012; 4: 357-65. doi: 10.2147/CMAR.S26133.

81. Mahalingam D, Mita M, Sarantopoulos J, Wood L, Amaravadi RK, Davis LE, Mita AC, Curiel TJ, Espitia CM, Nawrocki ST, Giles FJ, Carew JS. Combined autophagy and HDAC inhibition: a phase I safety, tolerability, pharmacokinetic, and pharmacodynamic analysis of hydroxychloroquine in combination with the HDAC inhibitor vorinostat in patients with advanced solid tumors. Autophagy. 2014; 10: 1403-14. doi: 10.4161/auto.29231.

82. Patel S, Hurez V, Nawrocki ST, Goros M, Michalek J, Sarantopoulos J, Curiel T, Mahalingam D. Vorinostat and hydroxychloroquine improve immunity and inhibit autophagy in metastatic colorectal cancer. Oncotarget. 2016; 7: 59087-97. doi: 10.18632/oncotarget.10824.

83. Zhang X, Chen L. The recent progress of the mechanism and regulation of tumor necrosis in colorectal cancer. $\mathrm{J}$ Cancer Res Clin Oncol. 2016; 142: 453-63. doi: 10.1007/ s00432-015-1997-z.

84. Kelly PN, Strasser A. The role of Bcl-2 and its pro-survival relatives in tumourigenesis and cancer therapy. Cell Death Differ. 2011; 18: 1414-24. doi: 10.1038/cdd.2011.17.

85. Scopa CD, Tsamandas AC, Zolota V, Kalofonos HP, Batistatou A, Vagianos C. Potential role of bcl-2 and ki-67 expression and apoptosis in colorectal carcinoma: a clinicopathologic study. Dig Dis Sci. 2003; 48: 1990-7.

86. Maiuri MC, Le Toumelin G, Criollo A, Rain JC, Gautier F, Juin P, Tasdemir E, Pierron G, Troulinaki K, Tavernarakis N, Hickman JA, Geneste O, Kroemer G. Functional and physical interaction between $\mathrm{Bcl}-\mathrm{X}(\mathrm{L})$ and a $\mathrm{BH} 3$-like domain in Beclin-1. EMBO J. 2007; 26: 2527-39. doi: 10.1038/sj.emboj.7601689.

87. Boise LH, Gonzalez-Garcia M, Postema CE, Ding L, Lindsten T, Turka LA, Mao X, Nunez G, Thompson CB. bcl-x, a bcl-2-related gene that functions as a dominant regulator of apoptotic cell death. Cell. 1993; 74: 597-608.

88. Jin-Song Y, Zhao-Xia W, Cheng-Yu L, Xiao-Di L, Ming S, Yuan-Yuan G, Wei D. Prognostic significance of Bcl-xL gene expression in human colorectal cancer. 
Acta Histochem. 2011; 113: 810-4. doi: 10.1016/j. acthis.2011.01.002.

89. Wei MC, Zong WX, Cheng EH, Lindsten T, Panoutsakopoulou V, Ross AJ, Roth KA, MacGregor GR, Thompson CB, Korsmeyer SJ. Proapoptotic BAX and BAK: a requisite gateway to mitochondrial dysfunction and death. Science. 2001; 292: 727-30. doi: 10.1126/ science. 1059108 .
90. Cobanoglu B, Ceyran AB, Simsek M, Senol S. Immunohistochemical analysis of Bax and AIF in colorectal tumors. Int J Clin Exp Med. 2015; 8: 16071-6.

91. Gil J, Ramsey D, Szmida E, Leszczynski P, Pawlowski P, Bebenek M, Sasiadek MM. The BAX gene as a candidate for negative autophagy-related genes regulator on mRNA levels in colorectal cancer. Med Oncol. 2017; 34: 16. doi: 10.1007/s12032-016-0869-y. 